\title{
THE ROLE OF E-LEARNING IN EDUCATIONAL PROCESSES
}

\author{
Aneta Duda', Sylwester Korga', Sebastian Gnapowski² \\ 1 Department of Fundamentals of Technology, Lublin University of Technology, Nadbystrzycka 38, 20-618 \\ Lublin, Poland, e-mail: a.duda@pollub.pl \\ 2 Department of Teaching Methods and Strategies, Lublin University of Technology, Nadbystrzycka 38, 20-618 \\ Lublin, Poland
}

Received: 2014.09.25

Accepted: 2014.10.25

Published: 2014.12.01

\begin{abstract}
The subject of this article contains selected methods of optimization of educational work using selected computer tools, such as e-learning. The use of information technologies is a common feature of teaching methods, which include e-learning. Through a distance learning, teaching and learning process became accessible from anywhere, at any age and time. Virtual contact between the teacher and the student is in many cases far more convenient for both of them. Training and e-learning courses are very popular. They are carried out not only in school or academic environment but also in the business one. Distance education is used as a tool to support learning process, and its use may allow easy management of materials, allowing to create flexible educational methods.
\end{abstract}

Keywords: e-learning, educational work, distant education, online education.

\section{INTRODUCTION}

Continuous development of information technology means that along with new technological solutions, implemented into common use, there are similar questions and problems to solve in education:

- what aspects of new technology should be adapted in schools?;

- what to learn about this technology and with its use?;

- how to prepare teachers to such changes?;

- how to teach in rapidly changing environment of learning, students functioning, schools and entire societies?

The awareness of changes associated with the development of information technology becomes the need of every human being, who with age, and gained education and life experience increasingly takes over education in their own hands. Changes in information technology occurring all the time cause that almost never any of the above raised issues will be finally solved. As an example of such problems one can enumerate the preparation of teachers in the field of information technology [4].

Continuous growth of knowledge forces the society to use time for education of younger generation efficiently. Nowadays, modern education is able to provide civilizational advancement of children and young adults. Being aware of the fact that students are critical and demanding recipients, and that the offer of the possibility of their education increases day by day, a proper preparation of information of every teacher has now become a significant issue. Therefore, quite often, experienced teachers decide to undertake additional studies in information technologies, especially with modern methods, in order to improve their educational workshop [2].

\section{CHARACTERISTICS OF DISTANCE TEACHING}

Literature contains many definitions of elearning. In order to better understand what distance teaching is, Figure 1 shows areas which 


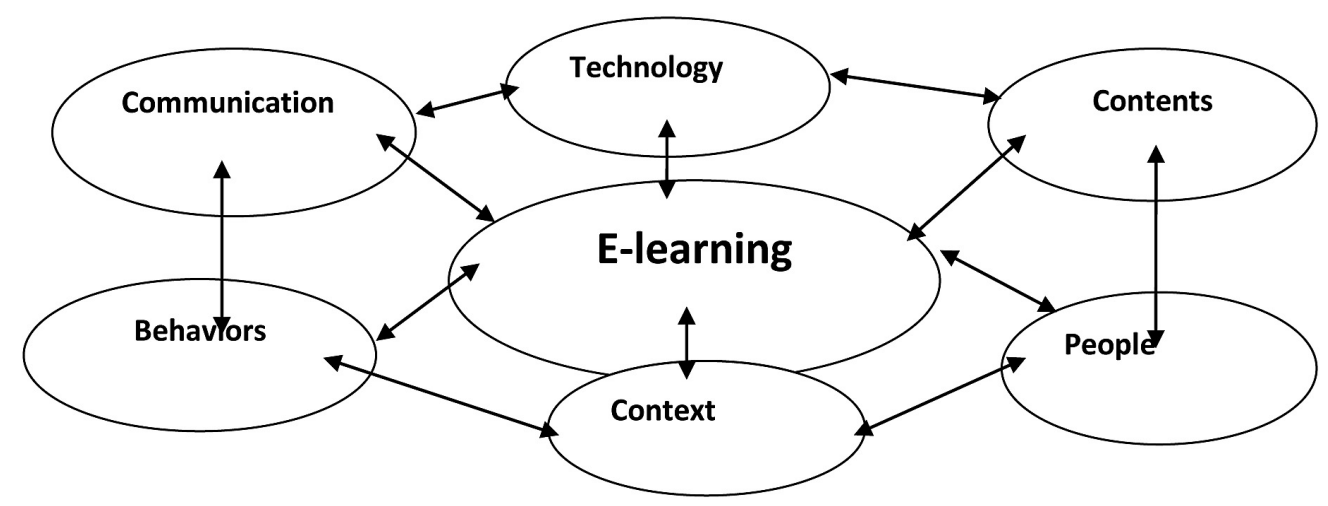

Fig. 1. Characteristics of e-learning [6]

includes distance teaching and relations existing between them.

These areas include the following issues:

1) Contents - electronic materials provided to students. The carriers of this information are CDs, applications and web-based tools. Their contents are mainly educational materials containing knowledge, exercises and tests. They may take aform of not only technologically advanced didactic materials (e.g. animations), but also text in *pdf format, or specific online resources [5].

Example of such materials can be, for instance materials for self-education in the form of text with illustrations available in *.doc, *.pdf, *.ppt format. These include animations, simulations and e-tests.

2) Technology, that is software and hardware used to create e-learning content. Software allows using all forms and modes of distance education. It is software designed to create etrainings, e-learning platform or supporting application. Hardware is designed to create and maintain technical infrastructure of elearning implementation. These are servers, links, etc.

3) Context - conditions in which training is implemented. The following issues are especially taken into account:

- training scale,

- training duration,

- scope of substantive training,

- nature of provided contents.

4) People - a group of target users of e-learning training, characterized by the following criteria:

- age,

- experience in the use of distance learning,
- computer competences,

- the time that can be spent on training by the group,

- attitude to distance education.

5) Communication - two groups can be be highlighted:

- communication of training is the way and form of the transfer of information about the objectives, methods of its realization, results and other such relevant information,

- communication during training is the form, manner and rules of communication of its participants including groups such as, e.g. coach-student, student-student.

6) Behaviors - defining psycho-social behaviors that occur during the training, related to the perception, understanding and experience of the training by its participants $[1,6,7]$.

\section{TEACHING AND LEARNING IN RELATION TO THE E-LEARNING}

"Learning" as opposed to "training" clearly shows the essence of the study of distance education, requiring self-discipline, commitment, motivation and understanding the necessity to build own competence.

Here, the trainee is an active part that must demonstrate initiative. We must find the will to improve qualifications and this is due to our needs there is a developed individual remotely delivered training program.

The meaning of the prefix " $\mathrm{e}$ " in the word "e-learning" in English is effective, entertaining, engaging, evolving, exciting, enhancing, extended etc [3]. 


\section{COMPARISON OF CONVENTIONAL TEACHING AND E-LEARNING}

Conventional educational activities differ significantly from e-learning education, but learning objectives and people acting of both methods are the same. The difference is only in applied mechanisms. In e-courses these mechanisms are used to allow for efficient acquisition of knowledge, skills, and increase competences without direct intervention of the teacher. Thus, e-learning can be another form of teaching that will support educational mechanisms used so far. Key messages of e-learning are as follows:

- just for me - trainings can be largely personalized or adjusted to the needs of the trainee;

- just in time - large time flexibility, training takes place when the need arises, so the education does not have to be rigorously fixed in time, and knowledge transfer can take place in addition to synchronous mode also in asynchronous one (e.g. without the requirement of teacher and student's simultaneous use of the platform);

- just enough - that is learning in sufficient level necessary for a person in order to raise his/her competence in the selected range [1].

Discussed demands can be realized in varying degrees. Individual ranges of the knowledge can be distinguished from the training content. Separate components of the whole process can be portable and stand-alone (in the sense of detachment from the overall course of the field). Due to e-learning courses substantive content can be made available to the learner all the time, so random class participation is entirely possible.

E-learning courses are collections of knowledge transferred in textual-graphic-audiovisual form, being, I turn, ordered set of screens displayed on a monitor. The advanced form of courses gives the ability to follow multiple paths of training or deepen the scope of presented knowledge due to links. It is also possible to build courses that adapt to the knowledge and skills of the trainee.

A number of components can be used, inter alia:

- initial and final tests,

- question and exercises during the lesson,

- standardized screens including texts, pictures, graphic schemes, animations, films, audio, links to additional resources and to other elements of the course,
- reference books, indexes,

- interludes breaking the monotony of the lesson and recapitulating key content of the medium,

- educational games and simulations.

An integral part of the course is the mechanism of navigation allowing smooth movement through the training content $[2,6]$.

\section{CORPORATE TRAININGS AS A SPECIFIC EXAMPLE OF E-LEARNING}

The idea of e-learning in corporations is the use of the Internet, CD-ROMs and other electronic tools to optimize business processes through the effective delivery of knowledge. Due to corporate e-learning, an organization is able to reduce costs of training by eliminating costs of accommodation, meeting rooms renting, staff and catering. E-learning course gives employees to quick and effective opportunities to supplement necessary knowledge. Corporation does not need to organize a large training group. The only thing is direction from training department to participate in the desired course. Distance courses bring the increase of employees' qualifications by providing them with structured knowledge, which can be accessed throughout their work [3].

To use of e-learning, corporations need efficient computer infrastructure. Not every company can afford the expensive servers. However, there is a possibility of courses outsourcing, where the entire responsibility for technical solutions is taken by an external company. E-learning courses require large initial costs associated with the implementation of learning management system (LMS), but these expenditures decrease with the increase of the number of courses and the frequency of their conduct.

Due to e-learning courses in corporation, training department can performed detailed statistics on the didactic progress of employees and can also precisely define what knowledge the student already has, and what trainings await him in the future. Training department is able to modify directly in training contents, so that materials used during them will always be up to date. The user can adjust the range, intensity, pace and level of the training to his/her own preferences. Each employee has the opportunity to participate in the course from anywhere at any time, which positively affects the sense of independence and enables better self-education. 
Trainees can communicate with other participants through the computer. They contact with each other via messengers, chats or video conferences. Trainees' motivation in the case of e-learning course may, however, be lower in comparison with stationary courses, since they require trainee's self-discipline. In this case, mentor monitoring trainees' progress is helpful [5].

\section{RECIPIENT OF E-LEARNING TRAINING - CHARACTERISTICS OF ON-LINE STUDENTS}

Generally, offers of e-leaning courses are addressed to companies, corporations and public administration, which care for improving the skills of employees and appreciate possibilities and benefits offered by the use of the Internet in the training process realized in an efficient and cost-effective way.

By entering into the construction of e-learning course in corporation, design company is facing a serious problem: how to convey a given range of knowledge to older people? This is closely related to the fact that adults already have their own worldview and experience proven in practice. The difficulty associated with adults learning is also unwillingness to be instructed by younger colleagues.

Another problem of experienced, older workers is their own, individual style of learning shaped by life experiences. With age, this style is becoming more and more shaped and it is difficult to change or improve. Individual style of learning can have a big impact not only on the way of learning but also on lifestyle, problem solving and decision making [8].

Users of on-line trainings often carry their habits form school to virtual class. The change of environment can enhance their existing habits.
However, lack of direct contact with the teacher can increase expectations and requirements of the student. At the same time, in the network, it is very difficult to motivate the student to systematic work. Table 1 shows differences in educational styles between on-line students and traditional ones $[2,4]$.

\section{CONCLUSIONS}

Discussed subject on e-learning should be understood as one of the possibilities to organize and conduct employees training courses and teaching at school. During the construction of training contents for e-learning courses, transparency and proper selection of teaching aids must be ensured. The process of teaching in e-learning means that the student is a central part in this type of education, but a teacher is a programming, controlling and evaluating individual.

Selection of appropriate teaching aids as well as appropriate methodological assumptions has a significant impact on the final form of teaching. The use of "effects" in training should be appropriately centered so that each user can find the content corresponding to him. Knowledge acquisition is different because of the age of the user - may be different in the elderly people than in the young participants. Some prefer quiet presentation, which will allow them to familiarize themselves with the content by reading the text on each screen. Others will avoid such screens. For the latter, lack of animation and interaction may cause boredom. If in the company work young people, then there is a greater likelihood that they will choose interactive training, like gamer or animations, while older people rather choose presentations. Taking this into account, it is possible to create interesting trainings that will involve both these groups of users. The most important

Table 1. Differences in educational styles between on-line students and traditional ones [2, 4]

\begin{tabular}{|l|l|l|}
\hline \multicolumn{1}{|c|}{ Model } & \multicolumn{1}{c|}{ Student using e-learning } & Student using traditional educational methods \\
\hline Work styles & Independence & Relying on others \\
\hline Communication styles & Indirect & Direct \\
\hline Kind of motivation & Advantage of internal motivation & Advantage of external motivation \\
\hline Attitude towards environment & Large assertiveness & Average assertiveness \\
\hline Time organization & Regularity & Planning fluency \\
\hline Cognitive attitude & Advantage of practical attitude & Theoretical and practical \\
\hline Reaction rate & secondary & Primary \\
\hline Cognitive styles & Analytical, critical & Synthetic \\
\hline
\end{tabular}


ise participant's involvement, including achieved through the use of appropriate form of exercises and tests verifying participants' knowledge. The use of appropriate animations, "effects" help the user to give correct answers to the questions.

\section{REFERENCES}

1. Bednarek J.: Media w nauczaniu. Seria: Szkoła, dydaktyka, zadania. MIKOM, Warszawa 2002.

2. Kubiak M.J.: Internet dla nauczycieli. Nauczanie na odległość. MIKOM, Warszawa 1997.

3. Hyla M.: E-learning. Od pomysłu do rozwiązania. Solidex, Kraków 2003.
4. Hyla M.: Przewodnik po e-learningu. Oficyna Ekonomiczna, Kraków 2005.

5. Dobek-Ostrowska B.: Podstawy komunikowania społecznego. Wydawnictwo Astrum, Wrocław 2004.

6. Pisarek W.: Wstęp do nauki o komunikowaniu. Wydawnictwa Akademickie i Profesjonalne, Warszawa 2008.

7. Krzyżanowski R., Gorzałkowski B.: Wokół problemów komunikacji i zarządzania. Humanistyka i nauki społeczne - Zeszyt nr 56, Wydawnictwo Politechniki Poznańskiej, Poznań 2007.

8. Bednarek J.: Multimedia w kształceniu. Państwowe Wydawnictwa Naukowe PWN/MIKOM, Warszawa 2006. 